\title{
Muuttunut työelämä heijastuu yliopiston arkeen
}

Vuoden tiedeartikkeli antaa äänen työelämän vaatimusten paineen alla elävälle yliopistotyöntekijälle.

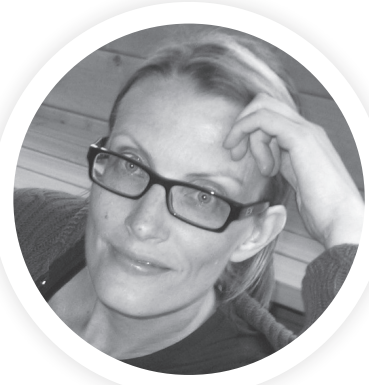

Tiina Nikkola

KT, FM, tutkijatohtori Opettajankoulutuslaitos Jyväskylän yliopisto

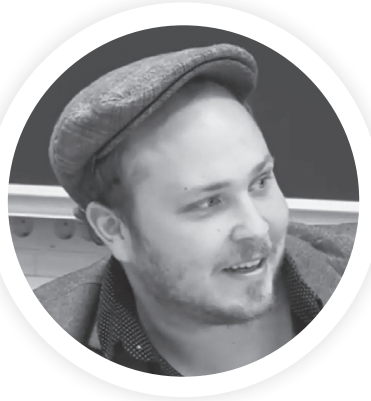

Esko Harni

YTM, KM, väitöskirjatutkija Kasvatustieteiden yksikkö Tampereen yliopisto
- KUN PALASIN TÖIHIN PERHEVAPAALTA, huomioni kiinnittyi monenlaisiin työelämän kummallisuuksiin. Päätin ryhtyä selvittämään, mitä työelämässä tapahtuu, kuvaa Aikuiskasvatus-lehden vuoden 2015 tiedeartikkelin toinen kirjoittaja Tiina Nikkola.

Artikkeli Sisäistyneet ristiriidat, tunnetyö ja tietotyöläissubjektiviteetin rakentuminen (Aikuiskasvatus 4/2015) kuvaa näitä kummallisuuksia, joihin lukeutuvat esimerkiksi työn muuttuminen yrittäjämäiseksi, vaatimukset työn tuottavuuden osoittamisesta ja yksilön vastuun korostuminen.

Nikkolan ja Harnin artikkeli tarkastelee näitä ilmiöitä yliopistotyöntekijöiden kokemusten kautta.
Haastateltavien kertomuksissa muuttunut työ ja sen organisoinnin tavat näyttäytyvät mahdottomana yrityksenä olla vaatimusten mukainen. Yliopisto, jota on pidetty sivistyksen, tieteen ja koulutuksen kehtona on tilanteessa, jossa sen toiminnalla odotetaan olevan esimerkiksi suoria vaikutuksia kansalliseen kilpailukykyyn. Vastuu tavoitteisiin päätymisestä siirtyy yhä enemmän yksittäiselle työntekijälle.

- Artikkelimme näkökulma tuo erityisen hyvin esiin työntekijöiden kokemusten tasolla sen ristiriitaisen tilanteen, johon yliopisto on viimeisten vuosien aikana päätynyt, Esko Harni pohtii. 
Aineistossa tutkijoita yllätti, miten osuvasti henkilökohtaiset kokemukset ilmensivät laajaa ja yleistä kertomusta työelämästä. Työntekijät kertovat hyvin henkilökohtaisista tunteista sekä pettymyksen ja jopa depression kokemuksista.

- Tutkimuksen aineisto kertoi yllättävänkin selvästi ja konkreettisesti niistä jännitteistä, joita olin aiemmin tutkinut hypoteettisella tasolla, Harni kertoo.

Työelämä patistaa yksilöä yhä tuottavampiin suorituksiin. Työntekijän tai työyhteisön hyvinvoinnin näkökulmasta tavoitteet kuitenkin kääntyvät jopa itseään vastaan.

- Tämänhetkisessä työelämässä pyrkimys olla hyvä työntekijä ja vastuullistaa itseään saattaa nurinkurisesti jopa estää organisaation ongelmien purkamista, koska ongelmat ovat yksilöä laajempia, eikä kaikki ole yksilön yritteliäisyydestä kiinni, Tiina Nikkola huomauttaa.

\section{KOULUTUSLEIKKAUKSET NÄKYVÄT ARJESSA}

Nikkolan ja Harnin tutkimusaihe on ajankohtainen. Se osuu keskelle aikaa, jossa yliopistojen rahoitusta leikataan rajusti ja keskustelu koulutuksen tuottavuudesta ja vaikuttavuudesta käy kiivaana.

- Leikkaukset ja jatkuva tuottavuuden vaatimus eivät pysähdy rakenteisiin, vaan ne valuvat arkeen ja tuntuvat ihmisten elämässä. Myös siinä, miten he itsensä näkevät ja itsestään puhuvat, Nikkola sanoo.

Kirjoittajien mukaan työelämää on tutkittava työntekijöiden kokemuksien kautta, koska ne paitsi kertovat työelämästä, myös heijastavat työelämän järjestämistä.

- Työelämän organisoinnin muutoksilla, joita usein perustellaan taloudellisilla lähtökohdilla ja pakoilla, vaikutetaan samalla vahvasti ihmisten jokapäiväiseen elämään, valinnan mahdollisuuksiin sekä kokemuksiin työelämästä, tutkijat summaavat.

\section{"Edistää keskustelua yliopistotyön ristiriidoista"}

Vuoden tiedeartikkelin valinnasta päättää Aikuiskasvatus-lehden toimituskunta. Palkittavaa artikkelia kiitetään sen ajankohtaisuudesta ja näkökulmasta, joka tuo esille liian vähän tutkitun aiheen: työntekijöiden kokemukset työelämän muutosten keskellä.

"Artikkeli on tarkkanäköinen ja teoreettisesti perusteltu analyysi siitä, mihin nykyinen yliopiston toimintalogiikka henkilöstön näkökulmasta voi johtaa", toimituskunta arvioi.

Palkitsemisperusteissa todetaan, että aineistonsa avulla tutkijat saavat esiin välineellisyyden, ajautumisen, irrallaan olemisen, eristäytymisen ja näkymättömissä pysyttelemisen kokemuksia, jotka eivät ole työn arjessa jaettavissa.

"Tietotyön ja yliopistotyöntekijöiden arjen kipukohtia ja syrjässä olemisen kokemuksia kirjoitetaan auki puhuttelevalla ja tuoreella tavalla", kirjoittajia kiitetään.

Nikkolan ja Harnin artikkeli osoittaa, miten yleiset työelämää ja koko yhteiskuntaa koskevat murrokset ja ristiriidat sisäistyvät työntekijöiden kertomuksissa hyvin yksityisiksi ongelmiksi, joiden laajempia syitä ja yhteyksiä ei pystytä tunnistamaan. Tämä on omiaan aiheuttamaan kokemuksia vaikutusmahdollisuuksien puuttumisesta nyky-yliopistossa, mikä synnyttää pettymyksen, depression ja epätoivon kokemuksia. Näitä kokemuksia kirjoittajat ovat onnistuneet aineistossaan tavoittamaan.

"Artikkelin kirjoittajat luovat artikkelillaan edellytyksiä puhua avoimesti yliopistoarjesta ja yliopistotyöhön liittyvistä ristiriidoista", toimituskunta kiittää.

Nikkola, T. \& Harni, E. (2015).

Sisäistyneet ristiriidat, tunnetyö ja

tietotyöläissubjektiviteetin rakentuminen.

Aikuiskasvatus 35(4), 244-253.

Helka Repo

toimituspäällikkö

Aikuiskasvatus 